\title{
ЭКОЛОГИЯ
}

DOI: https://doi.org/10.15688/jvolsu3.2019.2.13

UDC 502:911.37:502.131.1

Submitted: 12.04.2019

LBC 20.18

Accepted: 29.04.2019

\section{THE ENVIRONMENTAL ASSESSMENT OF URBAN AGGLOMERATIONS ON THE BASIS OF SUSTAINABLE DEVELOPMENT INDICATORS}

\author{
Elena A. Ivantsova \\ Volgograd State University, Volgograd, Russian Federation \\ Margarita V. Postnova \\ Volgograd State University, Volgograd, Russian Federation \\ Vadim A. Sagalaev \\ Volgograd State University, Volgograd, Russian Federation \\ Anna A. Matveeva \\ Volgograd State University, Volgograd, Russian Federation \\ Anna V. Kholodenko \\ Volgograd State University, Volgograd, Russian Federation
}

\begin{abstract}
The article discusses the indicators of sustainable development given from the standpoint of the classical concept of sustainable development. The methods used are analyzed to identify criteria for sustainable development. The indicators of sustainable development have been known and developed for a long time. However, their development did not take into account the regional fix, which would allow creating a permanent set of the most representative indicators for a certain territory. Volgograd and Rostov agglomerations are chosen as objects. A complex analysis of the regional indicators of sustainable development is carried out taking into account physiographic, climatic, sectoral features, the economic potential and ecological well-being of Volgograd and Rostov agglomerations. The work assesses the ecological and economic sustainability of the agglomerations under study, which allows to give the comparative analysis of the territory development predictive models. Today, it is still too early to talk about the effectiveness of achieving criteria for sustainable development in urban agglomerations. The accepted methods cannot be considered effective due to the fact that the efforts of all areas of management are needed. In the forecast, we can talk about a slight increase in the stability of Rostov agglomeration due to capital inflows. Taking into account current trends, Volgograd agglomeration can face a gradual decrease in sustainability requiring an immediate intervention.

Key words: concept of sustainable development, indicators of sustainable development, region, urban agglomeration, forecasting model of agglomeration development.

Citation. Ivantsova E.A., Postnova M.V., Sagalaev V.A., Matveeva A.A., Kholodenko A.V. The Environmental Assessment of Urban Agglomerations on the Basis of Sustainable Development Indicators. Vestnik Volgogradskogo gosudarstvennogo universiteta. Seriya 3, Ekonomika. Ekologiya [Science Journal of Volgograd State University. Global Economic System], 2019, vol. 21, no. 2, pp. 143-156. (in Russian). DOI: https:// doi.org/10.15688/jvolsu3.2019.2.13
\end{abstract}




\title{
ЭКОЛОГИЧЕСКАЯ ОЦЕНКА ГОРОДСКИХ АГЛОМЕРАЦИЙ НА ОСНОВЕ ИНДИКАТОРОВ УСТОЙЧИВОГО РАЗВИТИЯ
}

\author{
Елена Анатольевна Иванцова \\ Волгоградский государственный университет, г. Волгоград, Российская Федерация \\ Маргарита Викторовна Постнова \\ Волгоградский государственный университет, г. Волгоград, Российская Федерация \\ Вадим Александрович Сагалаев \\ Волгоградский государственный университет, г. Волгоград, Российская Федерация
}

Анна Александровна Матвеева

Волгоградский государственный университет, г. Волгоград, Российская Федерация

Анна Викторовна Холоденко

Волгоградский государственный университет, г. Волгоград, Российская Федерация

\begin{abstract}
Аннотация. В статье рассмотрены индикаторы устойчивого развития, данные с позиции классической Концепции устойчивого развития. Проанализированы методы, используемые для выявления критериев устойчивого развития. Индикаторы устойчивого развития известны уже давно, однако при их разработке не была учтена региональная привязка, которая позволила бы создать постоянный набор наиболее репрезентативных индикаторов для определенной территории. В качестве объектов были выбраны Волгоградская и Ростовская агломерации. Был проведен комплексный анализ региональных индикаторов устойчивого развития с учетом физико-географических, природно-климатических, отраслевых особенностей, экономического потенциала и экологического благополучия Волгоградской и Ростовской агломераций. В работе производилась оценка эколого-экономической устойчивости изучаемых агломераций, которая позволила дать сравнительный анализ прогнозных моделей развития территорий. В настоящий момент еще рано говорить об эффективности достижения критериев устойчивого развития в городских агломерациях. Принимаемые методы нельзя назвать эффективными в силу того, что требуются усилия всех областей хозяйствования. В прогнозе можно говорить о незначительном увеличении устойчивости Ростовской агломерации за счет притока капитала. В Волгоградской же агломерации, учитывая современные тенденции, может наблюдаться постепенное снижение устойчивости, требующее немедленного вмешательства.
\end{abstract}

Ключевые слова: концепция устойчивого развития, индикаторы устойчивого развития, регион, городская агломерация, прогнозная модель развития агломераций.

Цитирование. Иванцова Е. А., Постнова М. В., Сагалаев В. А., Матвеева А. А., Холоденко А. В. Экологическая оценка городских агломераций на основе индикаторов устойчивого развития // Вестник Волгоградского государственного университета. Серия 3, Экономика. Экология. - 2019. - Т. 21, № 2. - С. 143-156. DOI: https://doi.org/10.15688/jvolsu3.2019.2.13

\section{Введение}

Для достижения всеобщей экологической устойчивости необходимо оценить экологическую ситуацию в ключевых местах скопления населения - агломерациях. Эколого-географические характеристики определяют направление развития агломерации. В зависимости от структуры народного хозяйства меняется сте- пень антропогенного воздействия на окружающую среду. Таким образом, необходимо в рамках агломерации отразить и экологическую, и экономическую составляющие для полноценной оценки ее устойчивости.

\section{Результаты и обсуждение}

В настоящее время экономика России является структурно деформированной и неэффек- 
тивной. Ее негативное воздействие на окружающую среду существенно выше, чем в технологически передовых странах. Значительная часть основных производственных фондов России не отвечает современным экологическим требованиям, а около $20 \%$ ее территории, где проживает больше половины населения, характеризуются как экологически неблагополучные. Накопленный негативный эффект прошлых лет и специфика переживаемого переходного периода в экономике предопределяют сложность и болезненность необходимых преобразований.

В процессе перехода к Концепции устойчивого развития важна роль государственного управления, при этом одним из важных условий является создание отлаженной системы взаимодействия «центр - регионы» [Пакина и др., 2017].

Проблемы, решаемые в каждом регионе, в значительной степени должны соответствовать федеральным задачам, но при этом необходим учет местных особенностей, предусматривающий:

- формирование регионального хозяйственного механизма, регулирующего социально-экономическое развитие, в том числе природопользование и антропогенное воздействие на окружающую среду;

- выполнение природоохранных мероприятий на селитебных и незастроенных территориях городов, других населенных пунктов и в пригородных зонах, включая их санитарную очистку, рекультивацию земель, озеленение и благоустройство;

- осуществление мер по оздоровлению населения, развитию социальной инфраструктуры, обеспечению санитарно-эпидемиологического благополучия;

- развитие сельского хозяйства на основе экологически прогрессивных агротехноло- гий, адаптированных к местным условиям, реализация мер по повышению плодородия почв и их охране от эрозии и загрязнения, а также создание системы социальной защиты сельского населения;

- реконструкцию региональной промышленной системы с учетом хозяйственной емкости локальных экосистем [Пакина и др., 2017; Указ президента от 01.04.1996 № 440 ..., 2018].

В настоящий момент еще рано говорить об эффективности достижения критериев устойчивого развития в городских агломерациях. Принимаемые методы нельзя назвать эффективными в силу того, что требуются усилия всех областей хозяйствования. В настоящее время этого достичь невозможно ввиду практически отсутствия экологического сознания у большинства населения. В нормативно-правовой аппарат еще не удалось включить экологическую составляющую без противоречий с другими сферами деятельности.

Индикаторы устойчивого развития известны уже давно, однако при их разработке не была учтена региональная привязка, которая позволила бы создать постоянный набор наиболее репрезентативных индикаторов для определенной территории. Система включает в себя как базовые параметры (ВВП, площадь ООПТ и др.), так и дополнительные (площадь выбытия земель из сельскохозяйственного оборота). Для присвоения статуса устойчивого развития территории необходимо наблюдать экономический рост в совокупности с минимизацией воздействия на окружающую среду и улучшением качества жизни населения. Для этого используемые индикаторы должны выполнять следующие задачи (см. рисунок). Одним из самых значительных аспектов задач индикаторов устойчивого развития явля-

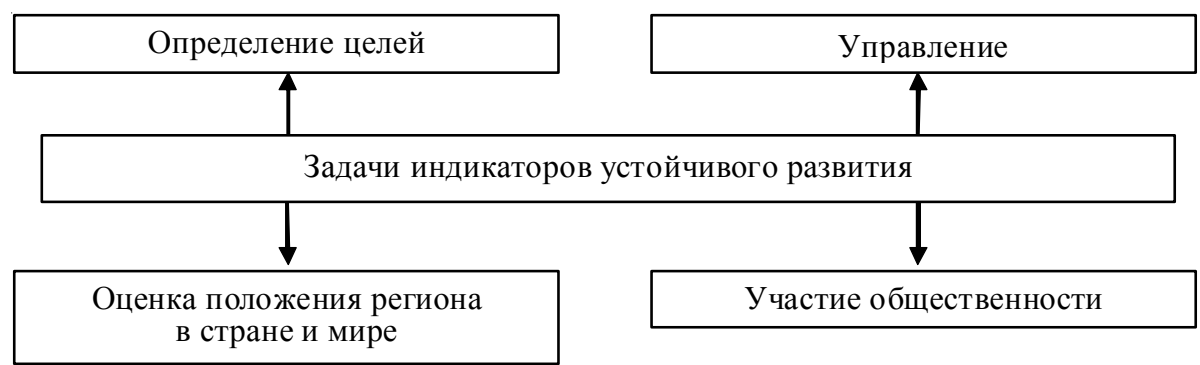

Рисунок. Задачи индикаторов устойчивого развития

Примечание. Составлено авторами по: [Бобылев и др., 2014; Устойчивое развитие ..., 2011; Sustainable ..., 2013]. 
ется участие общества в процессе создания благоприятной среды.

В зависимости от уровня применения системы индикаторы могут подразделяться на следующие уровни: федеральные, региональные и локальные, при этом для каждого уровня характерны индивидуальные особенности. Однако очень часто индикаторы, применяемые на локальном уровне, практически не имеют значения на федеральном уровне. Недостатками индикаторов федерального уровня являются их общность и усредненность; территория страны достаточно большая и ситуация в регионах очень сильно разнится.

Для эффективной оценки состояния окружающей среды необходимо разработать индикаторы, подходящие для разных уровней деятельности. К ним можно отнести показатели, отражающие уровень безработицы, образованности, площади особо охраняемых территорий и др.

Тем не менее в настоящее время существует проблема выбора наиболее репрезентативных индикаторов устойчивого развития. Среди основных индикаторов можно выделить динамику, степень чувствительности к изменениям и четкую направленность. В рамках динамики показатель должен отражать изменения, происходящие с течением времени. Он позволяет производить мониторинг состояния среды с учетом антропогенной деятельности. Индикатор должен быть чувствителен к малейшим изменениям внутренней среды, что позволит выявить проблему раньше, чем она может наступить. Важным критерием является ясность направления изменений. Необходимо четко отражать положительные или отрицательные тенденции происходящего.

Для разработки критериев нужно отследить их соответствие существующей политике. Они должны характеризовать наиболее важные существующие вопросы и ни в коем случае не противоречить текущей политике. Критерии должны быть связанными с принимаемыми в настоящий момент решениями.

Информация, отраженная в индикатоpax, должна быть доступна для понимания ключевыми заинтересованными сторонами. Данные, используемые для построения индикаторов должны быть достоверны, точны и надежны. Для этого необходимо учитывать частоту сбора данных и их согласование во времени. Получение такого рода данных в настоящее время является одним из ограничивающих факторов оценки устойчивости агломераций.

Самой полной системой индикаторов концепции устойчивого развития является система, предложенная Комиссией $\mathrm{OOH}$ по устойчивому развитию. Данные индикаторы охватывают четыре сферы воздействия: экологические (показатели сбросов, выбросов и т. д.), экономические (ВВП, ВРП, инвестиционные доходы), социальные (уровень здоровья населения, благополучия и т. д.), а также принято говорить о четвертой группе - институциональные индикаторы (планирование, нормативно-правовая деятельность) [Elkington, 2004; Polese et al., 2000; Urbaniec, 2015]. Роль и использование данных индикаторов может изменяться в зависимости от ситуации в какомлибо регионе, так как описанная система применяется как на глобальном уровне, так и на локальном. Более того, они содержат достаточно общую информацию, могут расширяться и корректироваться в случае необходимости.

Существует классификация данных индикаторов в зависимости от цели. Выделяют три группы индикаторов: воздействие, состояние и отклик. Первая из них представляет собой все аспекты прямого влияния человека на окружающую среду. В нее включены все процессы и характеристики деятельности, которые могут повлиять на устойчивое развитие какой-либо территории. Вторая категория дает оценку состояния окружающей среды в настоящий момент (резервы, природоемкость, биологическое разнообразие и др.). В категории реагирования (отклика) дается характеристика действиям человека, направленная на улучшение состояния окружающей среды и достижение устойчивости развития.

На территории РФ ранее уже активно применялись приоритетные базовые системы индикаторов устойчивого развития для оценки экологической ситуации отдельных регионов, однако данная система является недостаточно проработанной, так как там практически отсутствуют валовые показатели, такие как природоемкость. Позже были разработаны 13 добавочных ключевых индикаторов, 
которые включали в себя данные о шумовом загрязнении, доле населения, проживающего в экологически неблагоприятных условиях, доле переработанных и обезвреженных отходов и др. Одним из главных факторов является анализ количества личного автотранспорта и пассажирооборота общественного транспорта, ввиду скопления большого количества населения в центре города [Соловьева, 2014; ЦУР и Россия, 2018; Яшалова, 2014].

Согласно целям Концепции устойчивого развития, которые были определены для Российской Федерации, разработаны индикаторы, позволяющие судить об эколого-экономической устойчивости страны и регионов. Данные индикаторы были разделены на две группы: базовые и дополнительные. К базовым индикаторам относят показатели, которые отражают общую информацию о состоянии окружающей среды. В графе «дополнительные» указаны уточняющие параметры. Показатели обеих групп отражают информацию о наблюдаемом антропогенном воздействии, о текущем состоянии окружающей среды, а также о мерах, направленных на минимизацию негативного воздействия и повышение экологической устойчивости территорий [OОН и устойчивое развитие].

В качестве анализа были рассмотрены две крупные городские агломерации, входящие в состав одного федерального округа, однако имеющие определенные отличия по выделенным критериям экологической оцен- ки с учетом региональных индикаторов устойчивого развития: Волгоградская и Ростовская.

Волгоградская агломерация достаточно репрезентативна для анализа эколого-экономической устойчивости ввиду географических и климатических особенностей, а также из-за характера развития города и его экономики. Рельеф территории относительно выровненный. Агломерация имеет вытянутую вдоль реки Волга форму. Климат характеризуется как умеренно-континентальный с высокими температурами в летнее время и повышенной ветровой активностью в течение года [Информация об агломерации].

Основная специализация агломерации промышленное производство. На территории города находятся два промышленных узла: южный и северный. Тем не менее территория может быть внедрена в различные отрасли структуры народного хозяйства ввиду высокого природно-ресурсного потенциала. Основные данные для анализа экологической устойчивости Волгоградской агломерации представлены в таблице (табл. 1).

Волгоградская агломерация является достаточно крупной по своим размерам. Длина городского полукольца составляет около 80 км, а ширина 3-10 км. Длина агломерации 100 км, а общая площадь агломерации состав-

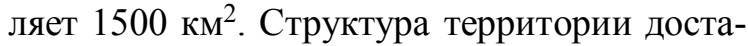
точно рыхлая, множество пустырей, занимающих места между районами города и между населенными пунктами [Информация об

Система индикаторов устойчивого развития для Волгоградской агломерации за 2017 г.

\begin{tabular}{|c|c|c|c|}
\hline Индикаторы & Группы & Параметры & $\begin{array}{c}\text { Данные по Волгоград- } \\
\text { ской агломерации }\end{array}$ \\
\hline ВРП, в \% к предыдущему году & \multirow{3}{*}{ Базовые } & Воздействие & 98,6 \\
\hline $\begin{array}{l}\text { Изменение площади сельскохо- } \\
\text { зяйственных земель }\end{array}$ & & Состояние & -76,1 тыс. га \\
\hline Площадь ООПТ & & Отклик & 1000782,4 га \\
\hline Общий объем выбросов & \multirow{8}{*}{$\begin{array}{l}\text { Дополни- } \\
\text { тельные }\end{array}$} & \multirow[t]{4}{*}{ Воздействие } & 161,4 тыс. т \\
\hline Образование отходов & & & $3529467,9 \mathrm{~T}$ \\
\hline Вылов рыбы & & & 4,8 тыс. т \\
\hline Вывозка древесины & & & 2,6 тыс. $\mathrm{m}^{3}$ \\
\hline $\begin{array}{l}\text { Изменения структуры землеполь- } \\
\text { зования }\end{array}$ & & \multirow[t]{2}{*}{ Состояние } & $\begin{array}{c}\text { Переведено между } \\
\text { категориями } 14,0 \text { га }\end{array}$ \\
\hline Лесопокрытая площадь & & & $4,3 \%$ \\
\hline Величина лесовосстановления & & \multirow[t]{2}{*}{ Отклик } & 1005,0 га \\
\hline $\begin{array}{l}\text { Инвестиции, направленные на } \\
\text { охрану окружающей среды }\end{array}$ & & & 1 375,2 млн руб. \\
\hline
\end{tabular}

Примечание. Составлено по: [Официальная статистика ... по Волгоградской обл., 2017]. 
агломерации; Официальная статистика ... по Волгоградской обл., 2017].

Основным показателем, отражающим экономическую деятельность региона, является ВРП, который включает в себя стоимость всех товаров и услуг, произведенных на территории агломерации. Сравнивая текущий показатель с предыдущим годом, можно увидеть его снижение на 1,4 \%. Это свидетельствует о том, что производство в городе и его окрестностях идет на спад. Как говорилось ранее, в структуре народного хозяйства Волгоградской агломерации преобладает промышленное производство. Основой являются предприятия машиностроения, металлообработки, металлургии, добывающей и нефтехимической промышленности, а также производства стройматериалов.

В настоящее время наблюдается увеличение доли обрабатывающих производств и сельского хозяйства на $1,3 \%$ соответственно. Уменьшение доли произошло в отраслях строительства (на 2,5\%) и торговли (на $1,8 \%$ ). Доля добывающих производств также снизилась, хоть и не была достаточно высокой. В 2016 г. она составляла 5,2\%, а в 2017 г. 4,8\%. Тем не менее нельзя не отметить, что данная отрасль даже при малом вмешательстве в экосистему наносит колоссальное воздействие на ее устойчивость.

Не менее важным является базовый показатель - изменение площади сельскохозяйственных земель. В настоящее время наблюдается уменьшение их площади на 76,12 тыс. га, что составляет примерно 0,7 \% от первоначальной территории. Указанные земли являются ценными, так как на территории области преобладают каштановые и черноземные типы почв. Они являются очень плодородными, что становится одним из ключевых факторов определения высокого уровня природно-ресурсного потенциала. Перевод таких земель в другие категории говорит об их истощении.

Основой экологической устойчивости региона является ее экологический каркас. Его базовыми элементами являются особо охраняемые территории. Волгоградская агломерация находится на территории Европейской части России, где большая часть земель антропогенно преобразована, а следовательно не может быть отнесена к ООПТ. В Волгоградской области площадь особо охраняемых природных территорий составляет 1000 782,4 га, что занимает $8,86 \%$ от общей территории. Данный показатель можно квалифицировать как «неудовлетворительный», так как доля ООПТ должна составлять не менее $10 \%$ для успешного выполнения природоохранной функции [Официальная статистика ... по Волгоградской обл., 2017].

Особенно острыми проблемами для Волгоградской агломерации являются данные, отраженные в рамках дополнительных индикаторов. Особенно высокое воздействие оказывается на атмосферный воздух. В 2017 г. выбросы от стационарных источников составили 161,4 т, но гораздо большее влияние оказывают передвижные источники. Негативным фактором выступает сама форма агломерации. В ходе жизнедеятельности происходит постоянное передвижение человеческих потоков в сторону центра агломерации. Данный факт обусловливает частое использование транспортных средств и увеличение выбросов парниковых газов, что резко негативно сказывается на экологической устойчивости агломерации [Официальная статистика ... по Волгоградской обл., 2017].

Проблема утилизации отходов Волгоградской агломерации также является актуальной. Она напрямую связана с текущей жизнедеятельностью и экономической деятельностью. Всего за 2017 г. были произведены 3529 467,9 т отходов всех категорий [Полигоны ТБО ...]. Главная проблема агломерации - сложность утилизации и обезвреживания ввиду отсугствия достаточного количества полигонов [Иванцова, 2016]. Также существует проблема накопленного мусора. В черте города и за его пределами можно наблюдать большое количество несанкционированных свалок. Они являются дополнительными источниками загрязнения окружающей среды.

Изменение структуры землепользования является достаточно репрезентивным показателем, так как отражает динамику изменений. Всего с 2013 по 2017 гг. между категориями были переданы 439,6 га земель. В каждый из перечисленных годов происходило перемещение земель из категории земель сельскохозяйственного назначения в категорию зе- 
мель промышленности и иного назначения. Исключения составляют 2013 г. (переход происходил также из земель ООПТ) и 2014 г. (дополнительно переход был в земли ООПТ). В 2017 г. произошел переход 140167 га из земель сельскохозяйственного назначения в земли промышленности и иного специального назначения. Стоит отметить, что площади остальных категорий не изменяются в течение времени [Плякин и др., 2012].

Основным стабилизатором экологической ситуации являются леса. В Волгоградской агломерации лесопокрытая площадь составляет 4,3\%. Чаще всего леса произрастают по берегам рек, по балкам, а также в лесостепной зоне на севере области. Их основная функция - защитная. Негативным фактором, усугубляющим существующую проблему, является достаточно сухой климат и наличие Волжской ГЭС. В ходе работы гидроэлектростанции произошло зарегулирование речного стока и, как следствие, изменение гидрологического режима территорий. Большая часть ранее затапливаемой территории в настоящее время не получает влаги, что приводит к ухудшению состояния растительности. В такой ситуации велика роль лесовосстановления. Всего с 2013 г. были высажены 5032 га леса. В 2017 г. величина лесовосстановления составила 1005 га [Официальная статистика ... по Волгоградской обл., 2017].

Для эффективного развития агломерации без ущерба экологической устойчивости необходимы инвестиции в природоохранную деятельность. В настоящее время наблюдается спад инвестиционной активности. В 2017 г. инвестиции в основной капитал, направленные на охрану окружающей среды и рациональное использование природных ресурсов, составили 1375,2 млн руб. (1 202,8 млн руб. были направлены на охрану и рациональное использование водных ресурсов) [Официальная статистика ... по Волгоградской обл., 2017].

Оценка экологической устойчивости Волгоградской агломерации показала, что регион обладает достаточно высоким уровнем природно-ресурсного потенциала. Тем не менее нельзя говорить о высоком уровне экологоэкономической устойчивости. В настоящее время наблюдается увеличение негативного воздействия с точки зрения автотранспорта, отходов производства и потребления. К положительным факторам можно отнести высокие темпы лесовосстановления и инвестирование в защиту водных ресурсов.

Ростовская агломерация достаточно интересна для детального анализа, так как на территории области существуют предпосылки для наращивания экономического потенциала. Площадь данной агломерации составляет 5,8 тыс. км ${ }^{2}$ с численностью населения более 2 млн человек. Рельеф выровненный, нет естественных преград. Климат теплый и, как в Волгоградской агломерации, с жарким и сухим летом. Однако на западе агломерации климат значительно мягче, что можно объяснить выходом к морю. Ростовская агломерация имеет овальную форму, вытянутую с запада на восток [Бредихин, 2016; Краткий статистический ..., 2017; Официальная статистика ... по Ростовской обл., 2017].

Основными отраслями хозяйствования в Ростовской агломерации являются сельское хозяйство, энергетика, добывающая промышленность, машино- и приборостроение. В целом агломерация интенсивно развивается в настоящее время. Ввиду глобального освоения данной территории степень негативных воздействий на окружающую среду достаточно высока. Одним из главных потенциально опасных объектов является Ростовская АЭС, которая в случае чрезвычайной ситуации может привести к необратимым последствиям. Необходимо оценить экологическую устойчивость Ростовской агломерации с использованием индикаторов устойчивого развития (см. табл. 2).

Анализируя ВРП региона, можно говорить об увеличении темпов экономического роста. Данные за 2017 г. превышают на 2,8 \% показатели предыдущих годов. Ситуацию можно объяснить увеличением темпов промышленного производства добывающей отрасли. Это касается добычи угля (в том числе антрацита) и прочих ископаемых. Объемы добычи нефти снизились на 1,3 \% по сравнению с 2016 г., однако сравнительно больше стало производиться продуктов химической и нефтехимической отраслей (производство лекарств, пластика и др.) [Официальная статистика ... по Ростовской обл., 2017]. 
Система индикаторов устойчивого развития для Ростовской агломерации за 2017 г.

\begin{tabular}{|c|c|c|c|}
\hline Индикаторы & Группы & Параметры & $\begin{array}{c}\text { Данные по Ростовской } \\
\text { агломерации }\end{array}$ \\
\hline ВРП, в \% к предыдущему году & \multirow{3}{*}{ Базовые } & Воздействие & 102,8 \\
\hline $\begin{array}{l}\text { Изменение площади сельскохо- } \\
\text { зяйственных земель }\end{array}$ & & Состояние & -51,7 тыс. га \\
\hline Площадь ООПТ & & Отклик & 415022,85 га \\
\hline Общий объем выбросов & \multirow{8}{*}{$\begin{array}{c}\text { Дополни- } \\
\text { тельные }\end{array}$} & \multirow[t]{4}{*}{ Воздействие } & 169,1 тыс. т \\
\hline Образование отходов & & & $3988201,4 \mathrm{~T}$ \\
\hline Вылов рыбы & & & 22,1 тыс. $\mathrm{T}$ \\
\hline Вывозка древесины & & & - \\
\hline $\begin{array}{l}\text { Изменения структуры землеполь- } \\
\text { зования }\end{array}$ & & \multirow[t]{2}{*}{ Состояние } & $\begin{array}{c}\text { Переведено между } \\
\text { категориями } 1 \text { тыс. га }\end{array}$ \\
\hline Лесопокрытая площадь & & & $2,4 \%$ \\
\hline Величина лесовосстановления & & \multirow[t]{2}{*}{ Отклик } & 1145 га \\
\hline $\begin{array}{l}\text { Инвестиции, направленные на } \\
\text { охрану окружающей среды }\end{array}$ & & & 5 941,2 млн руб. \\
\hline
\end{tabular}

Примечание. Составлено авторами по: [Официальная статистика ... по Ростовской обл., 2017].

В 2017 г. наблюдалось уменьшение площади сельскохозяйственных земель на 51,7 тыс. га, что составило примерно $0,7 \%$ от предыдущих территорий. Вывод изначально плодородных земель (большей частью черноземов) вызван их деградацией. Земли сельскохозяйственного назначения активно используются в Ростовской агломерации. Такой показатель можно отнести к положительным, при этом, рассматривая его в динамике, можно сделать вывод, что в предыдущие годы ежегодный вывод земель из оборота был в два раза больше. Этот факт говорит о привлечении внимания к экологическим проблемам сельского хозяйства и возможном уменьшении негативного воздействия в будущем [Площадь сельскохозяйственных угодий].

Как говорилось ранее, ООПТ являются одними из главных факторов формирования экологически устойчивой территории. В Ростовской агломерации такие земли имеют площадь 415022,85 га, что составляет 4,2\% от общей площади региона. Ввиду сухости климата и малой лесообеспеченности такое количество ООПТ крайне мало. Данная ситуация сложилась исторически в ходе заселения все большего количества территорий и увеличения антропогенной нагрузки на них. Территорий с нетронутой природой практически нет. Тем не менее высокую экологическую ценность представляет собой река Дон. По ее берегам и в водах можно встретить особо ценные виды, которые являются частью уникаль- ных экосистем [Официальная статистика ... по Ростовской обл., 2017].

Проблема загрязнения атмосферного воздуха является особо актуальной в Ростовской агломерации. Выброс от стационарных источников составляет 169,1 тыс. т, однако основным загрязнителем воздушного бассейна является автомобильный транспорт. Ежегодно наблюдается рост количества загрязняющих веществ в атмосфере. Согласно последним данным в главных городах агломерации - Ростов-на-Дону, Новочеркасск, Азов уровень загрязнения воздуха характеризуется как очень высокий. В Волгодонске - высокий, в городах Таганрог и Шахты - повышенный, в Цимлянске - низкий.

Как и в любом густонаселенном месте, в Ростовской агломерации существует проблема утилизации отходов. Тем не менее ее нельзя охарактеризовать как критическую. Всего за 2017 г. были образованы 3988 201,4 т отходов. Из общего числа отходов переданы на утилизацию $46,65 \%$, из них были обезврежены 5,6\%. В настоящее время более $50 \%$ отходов размещаются на временных полигонах и несанкционированных свалках. С точки зрения управления отходами существует необходимость разработки комплексной системы со вторичными материальными ресурсами, включающая в себя генеральные схемы очистки территорий населенных пунктов муниципальных образований Ростовской области. Основой для данного вида работ должна 
стать концепция обращения с отходам на долгосрочную перспективу [Официальная статистика ... по Ростовской обл., 2017].

Территория Ростовской агломерации относится к водообеспеченным, и поэтому одним из направлений хозяйствования является рыбная ловля. Всего здесь развиваются три направления аквакультуры: прудовое, индустриальное и пастбищное рыболовство. В 2017 г. улов рыбы составил 22,1 тыс. т, а улов водных биоресурсов - 13,4 т. Это направление хозяйствования является одним из приоритетных, так как невысоки затраты на производство, а влияние на окружающую среду минимально (при рациональном подходе).

В структуре земельного фонда Ростовской агломерации преобладают земли сельскохозяйственного назначения. Они составляют $87,5 \%$ от общего количества территории. Далее следуют земли населенных пунктов $-4,5 \%$. Следует отметить, что их большая часть относится к землям сельских населенных пунктов. Земли лесного фонда превосходят лесопокрытые территории $-3,4 \%$. К землям водного фонда относятся $2,2 \%$, а к землям запаса $-1,4 \%$. Землями промышленности и иного специального назначения заняты лишь 0,9 \% всей территории Ростовской области. Самой малочисленной территорией обладают земли особо охраняемых территорий и объектов $(0,1 \%)$ [Официальная статистика ... по Ростовской обл., 2017].

В 2017 г. произошел перевод между категориями земель сельскохозяйственного назначения, земель населенных пунктов, запаса и земель промышленности, энергетики, транспорта и т. д. Из земель запаса и земель населенных пунктов был перевод 0,5 тыс. га в земли сельскохозяйственного назначения. Из последней были выделены земли в пользу земель промышленности, энергетики, транспорта и т. д. также в размере 0,5 тыс. га [Официальная статистика ... по Ростовской обл., 2017].

Лесистость Ростовской агломерации составляет $2,4 \%$, что крайне мало для такой территории. Большая часть лесов выполняет защитную функцию (вокруг водоемов и в понижениях рельефа). Более того, около $80 \%$ лесов являются искусственными. Величина восстановления лесов в 2017 г. составила 1145 га, что соотносится с довольно высоким уровнем восстановления.
Отклик человека на изменения среды в ответ на его действия может носить характер инвестиций. Ростовская область характеризуется как инвестиционно привлекательный регион. В 2017 г. объем инвестиций в природоохранную деятельность составил 5,9 млрд рублей. Эта категория включает в себя инвестиции на охрану атмосферного воздуха, почв и земельных ресурсов, водных объектов [Официальная статистика ... по Ростовской обл., 2017].

Анализируя эколого-экономическую устойчивость Ростовской агломерации, в первую очередь можно увидеть резкое несоответствие интересов экономики и экологии. В регионе наблюдается экономический рост, но вместе с ним экспоненциально растет и антропогенное воздействие на окружающую среду. Более того, присутствует экологический ущерб прошлых лет. Основные отрасли хозяйствования (сельское хозяйство и добыча полезных ископаемых) характеризуются максимальным негативным воздействием на окружающую среду, включающим изменение рельефа и компонентное загрязнение. Положительным аспектом может служить наличие выхода к Азовскому морю и отсутствие природных преград для воздушных масс, что позволяет загрязнителям быстро ассимилироваться в воздушной и водной средах.

Волгоградская и Ростовская городская агломерации обладают сходными эколого-географическими характеристиками и на текущий момент времени они находятся примерно на одном уровне эколого-экономической устойчивости (см. табл. 3).

Учитывая показатели таблицы, можно говорить о снижении устойчивости Волгоградской агломерации. Степень износа основных фондов более $50 \%$. Долю численности безработных (почти $9 \%$ ) нельзя охарактеризовать как низкий показатель. Наблюдается отток населения в наиболее экономически выгодные регионы, в том числе в Ростовскую область. Высокий уровень выброса и сброса загрязнителей говорит о низком качестве оборудования, следовательно продукция менее конкурентоспособна на рынке. Негативными тенденциями характеризуется также уменьшающийся приток инвестиций на охрану окружающей среды. Данная ситуация связана с понижением инвестиционной привлекательности региона. 


\section{Сравнительный анализ Волгоградской и Ростовской агломераций} по индикаторам устойчивого развития за 2016 г.

\begin{tabular}{|l|c|c|}
\hline \multicolumn{1}{|c|}{ Индикатор устойчивого развития } & $\begin{array}{c}\text { Ростовская } \\
\text { агломерация }\end{array}$ & $\begin{array}{c}\text { Волгоградская } \\
\text { агломерация }\end{array}$ \\
\hline Инвестиции в основной капитал, млрд руб. & 287,4 & 181,5 \\
\hline Степень износа основных фондов, \% & 41,7 & 56,4 \\
\hline Ожидаемая продолжительность жизни, лет & 72,2 & 72,5 \\
\hline Численность безработных, тыс. чел. & 125,9 & 88 \\
\hline $\begin{array}{l}\text { Загрязнение атмосферы стационарными и } \\
\text { передвижными источниками, тыс. т }\end{array}$ & 629,2 & 441,7 \\
\hline $\begin{array}{l}\text { Поступление загрязненных сточных вод в } \\
\text { водный бассейн, млн м }\end{array}$ & 588 & 104,7 \\
\hline ВРП, в \% к предыдущему году & 102,8 & 98,6 \\
\hline
\end{tabular}

Примечание. Составлено авторами по: [Краткий статистический сборник ..., 2017; Официальная статистика ... по Волгоградской обл., 2017; Официальная статистика ... по Ростовской обл., 2017].

\section{Заключение}

Оценивая соответствие проблем планируемым действиям на территории агломерации, можно сделать вывод о небольших позитивных изменениях в эколого-экономической устойчивости агломерации. Основу прогнозной модели составляют данные о способах повышения инвестиционной привлекательности региона, но в то же время недостаточно четко прописаны планируемые действия с полученными средствами [Матвеева и др., 2018].

Ростовская агломерация обладает большим потенциалом повышения эколого-экономической устойчивости в будущем с точки зрения инвестирования. С каждым годом наблюдается рост вложений в охрану окружающей среды. Тем не менее нельзя данный показатель рассматривать отдельно от количества объектов, нуждающихся в охране. В Ростовской агломерации достаточно высокие уровни загрязнения всех компонентов окружающей среды, что требует значительных вложений в охрану окружающей среды, а также внедрение НДТ в технологический цикл всех предприятий, особенно угольной промышленности [Муниципальная программа ... ; Отчет об исполнении ...].

Для обоих агломераций актуальна проблема загрязнения атмосферного воздуха. Так как территория Ростовской области к тому же и малолесная, уменьшаются способности атмосферы к самоочищению. В настоящий момент наблюдается тенденция к снижению загрязнения воздуха и количество уловленных и обезвреженных загрязняющих веществ зна- чительно превосходит количество выброшенных в текущий период. Причем данная ситуация сохраняется на протяжении пяти лет. Объяснением может служить то, что большая часть загрязнителей поступает не от стационарных источников, а от передвижных.

При сохранении текущих тенденций будет наблюдаться ухудшение состояния здоровья населения, глобальное изменение микроклимата агломерации, ухудшение качества почв и прилегающих водных объектов, что ставит проблему загрязнения атмосферного воздуха на первое место как экономически затратное мероприятие.

В плане развития агломерации до 2020 г. большое внимание уделяется охране водных объектов. Наименее инвестируемыми за исследуемый период с 2012 по 2016 гг. оказались земельные ресурсы. Учитывая текущий эксплуатационный режим почв, большую вовлеченность площадей в хозяйственный цикл, можно говорить о скором снижении их продуктивности.

С точки зрения развития экологического образования в Ростовской и Волгоградской агломерациях существует множество образовательных ресурсов, общественных организаций и советов, которые повсеместно привлекают внимание к проблемам экологии.

Анализ прогнозных моделей, основанных на экологической оценке индикаторов устойчивого развития, позволит выявить реальные социо-эколого-экономические проблемы городских агломераций и найти оптимальные пути их решения с использованием именно институциональных факторов устойчивого развития. 


\section{СПИСОК ЛИТЕРАТУРЫ}

Бобылев, С. Н. Индикаторы устойчивого развития для городов / С. Н. Бобылев, О. В. Кудрявцева, С. В. Соловьева // Экономика региона. 2014. - № 3. - С. 101-110.

Бредихин, А. В. Ростовская агломерация: интеграционные приоритеты развития / А. В. Бредихин // Вопросы территориального развития. -2016 . - № 4 (34). - С. 1-14.

Иванцова, Е. А. Проблемы и перспективы управления твердыми бытовыми отходами / Е. А. Иванцова // Вестник Волгоградского государственного университета. Серия 3, Экономика. Экология. - 2016. - № 2 (35). - С. 148-159. DOI: https://doi.org/10.15688/jvolsu3.2016.2.15.

Информация об агломерации // Волгоградская городская агломерация от 07.05.18. - Электрон. текстовые дан. - Режим доступа: http:// bkd.rosdornii.ru/agglomeration/volgogradskaya. Загл. с экрана.

Краткий статистический сборник «Ростовская область в цифрах» 2017 г. // Федеральная служба государственной статистики от 01.06.18. - Электрон. текстовые дан. - Режим доступа: http:// rostov.gks.ru/wps/wcm/connect/rosstat ts/rostov/ resources/703392004156562e806d85a3e-1dde74c/ maket\%212016.pdf.-Загл. с экрана.

Матвеева, А. А. Оценка экологической устойчивости развития Волгоградской агломерации на основе индикаторов устойчивого развития / А. А. Матвеева, Е. А. Герусова // Ландшафтная география в XXI веке : материалы международной научной конференции «Третьи ландшафтно-экологические чтения, посвященные 100-летию со дня рождения Г.Е. Гришанкова» (г. Симферополь, 11-14 сент., 2018 г.) / ред. Е. А. Позаченюк [и др.]. - Симферополь : АРИАЛ, 2018. - С. 410-414.

Муниципальная программа от 24.11.2011 «Проект стратегии социально-экономического развития Ростовской области на период до 2020 года» // Официальный портал Правительства Ростовской области. - Электрон. текстовые дан. - Режим доступа: https:/www.donland.ru (дата обращения: 27.05.2018). - Загл. с экрана.

ООН и устойчивое развитие // Устойчивое развитие- основные темы от 15.05.18. - Электрон. текстовые дан. - Режим доступа: http:// www.un.org/ru/sections/general/un-andsustainability/index.html. - Загл. с экрана.

Отчет об исполнении плана реализации государственной программы Ростовской области «Охрана окружающей среды и рациональное природопользование» // Официальный портал Правительства Ростовской области. -
Электрон. текстовые дан. - Режим доступа: https://www.donland.ru (дата обращения: 30.05.2018). - Загл. с экрана.

Официальная статистика // Территориальный орган Федеральной службы государственной статистики по Волгоградской области от 26.05.18. Электрон. текстовые дан. - Режим доступа: http://volgastat.gks.ru/wps/wcm/connect/ rosstat ts /ru/statistics. - Загл. с экрана.

Официальная статистика // Территориальный орган Федеральной службы государственной статистики по Ростовской области от 26.05.18. - Электрон. текстовые дан. - Режим доступа: http:// rostov.gks.ru/wps/wcm/connect/rosstat_ts $/ \mathrm{ru} /$ statistics/employment. - Загл. с экрана.

Пакина, А. А. Оценка устойчивости развития на региональном уровне: пример Республики Татарстан / А. А. Пакина, С. Н. Кириллов, Н. И. Тульская // Вестник Волгоградского государственного университета. Серия 3, Экономика. Экология. - 2017. - № 4. - С. 127137. - DOI: https://doi.org/10.15688/ jvolsu3.2017.4.14.

Площадь сельскохозяйственных угодий Ростовской области // Сельское хозяйство и АПК от 13.06.18. - Электрон. текстовые дан. - Режим доступа: http://www.donland.ru/Default. aspx?pageid=89760. - Загл. с экрана.

Плякин, А. В. Пространственный анализ структуры земельного фонда Волгоградской области в геоинформационной системе / А. В. Плякин, Е. А. Орехова, В. Н. Бодрова // Вестник Волгоградского государственного университета. Серия 11, Естественные науки. - 2012. № 2 (4). - C. 65-72. - DOI: https://doi.org/ 10.15688/jvolsu1 1.2012.2.10.

Полигоны ТБО Волгоградской области // Волга-медиа от 15.06.18. - Электрон. текстовые дан. Режим доступа: http://vlg-media.ru/society/ poligony-tbo-v-volgogradskoi-oblasti-osnastjatmusoropererabatyvayuschimi-kompleksami59321.html. - Загл. с экрана.

Соловьева, С. В. Экологически устойчивое развитие Москвы: индикаторы и индексы / С. В. Соловьева // Социология и естествознание: междисциплинарные подходы к изучению социальной реальности : сб. науч. ст. и материалов Всерос. науч. конф.-М., 2014.-С. 24-27.

Указ Президента Российской Федерации от 01.04.1996 № 440 «О Концепции перехода Российской Федерации к устойчивому развитию». - Доступ из справ.-правовой системы «КонсультантПлюс».

Устойчивое развитие: методология и методики измерения : учеб. пособие / С. Н. Бобылев [и др.] ; под ред. С. Н. Бобылева. - М. : Экономика, 2011.-358 c. 
ЦУР и Россия // Цели устойчивого развития от 18.04.18. - Электрон. текстовые дан. - Режим доступа: http://www.globalcompact.ru /index/czeli-ustojchivogo-razvitiya.html. - Загл. с экрана.

Яшалова, Н. Н. Анализ проявления эффекта декаплинга в эколого-экономической деятельности региона / Н. Н. Яшалова // Региональная экономика: теория и практика. - 2014. № 39. - C. 54-61.

Elkington, J. The Triple Bottom Line: Does it All Add Up? Assessing the Sustainability of Business and CSR / J. Elkington ; ed. by A. Henriques, J. Richardson. - London : Earthscan Publications, 2004. - P. 1-16.

Polese, M. The Social Sustainability of Cities: Diversity and Management of Change / M. Polese, R. Stren. - Toronto : University of Toronto Press, 2000. - P. 15-16.

Sustainable Development in Russia / ed. by S. Bobylev, R. Perelet. - Berlin ; St. Petersburg : [s. n.], 2013. $-206 \mathrm{p}$.

Urbaniec, M. Sustainable Development Indicators in Poland: Measurement and System Evaluation / M. Urbaniec // Entrepreneurial Business and Economics Review. - 2015. № 1. - P. 119-133.

\section{REFERENCES}

Bobylev S.N. Indikatory ustojchivogo razvitija dlja gorodov [Indicators of sustainable development for cities]. Jekonomika regiona, 2014, no. 3, pp. 101-110.

Bredihin A.V. Rostovskaja aglomeracija: integracionnye prioritety razvitija [Rostov agglomeration: integration development priorities]. Voprosy territorial'nogo razvitija, 2016, no. 4 (34), pp. 1-14.

Ivantsova E.A. Problemy I perspektivy upravlenia tverdymi bytovymi othodami [Problems and prospects of solid waste management ]. Vestnik Volgogradskogo gosudarstvennogo universiteta. Seria 3, Jekonomika. Jekologija [Science Journal of Volgograd State University. Global Economic System], 2016, no. 2, pp. 148-159. DOI: https://doi.org/ 10.15688/jvolsu3.2016.2.15.

Informacija ob aglomeracii. Volgogradskaja gorodskaja aglomeracija ot 07.05.18. URL: http://bkd.rosdornii.ru/agglomeration/ volgograskaya/ (accessed 20 February 2018).

Kratkij statisticheskij sbornik «Rostovskaja oblast' v cifrah» 2017 g. Federal'naja sluzhba gosudarstvennoj statistiki ot 01.06.18. URL: http://rostov.gks.ru/wps/wcm/connect/ rosstat_ts/rostov/resources/703392004 156562e806d85a3e1dde74c/maket\%212016.pdf (accessed 26 January 2018).

Matveeva A.A, Gerusova E.A. Ocenka jekologicheskoj ustojchivosti razvitija Volgogradskoj aglomeracii na osnove indikatorov ustojchivogo razvitija [Assessment of environmental sustainability of the Volgograd agglomeration based on sustainable development indicators]. Pozachenjuk E.A. et al., eds. Landshaftnaja geografija $v$ XXI veke: materialy mezhdunarodnoj nauchnoj konferencii "Tret'i landshaftno-jekologicheskie chtenija, posvjashhennye 100-letiju so dnja rozhdenija G.E. Grishankova», Simferopol', 11-14 sentjabrja, 2018 g. Simferopol': IT «ARIAL», 2018, pp. 410-414.

Municipal'naja programma ot 24.11.2011 «Proekt strategii social'no-jekonomicheskogo razvitija Rostovskoj oblasti na period do 2020 goda». Oficial'nyj portal Pravitel'stva Rostovskoj oblasti (accessed 10 December 2018).

OON i ustojchivoe razvitie. Ustojchivoe razvitie osnovnye temy ot 15.05.18. URL: http:// www.un.org/ru/sections/general/un-andsustainability/index.html (accessed 29 January 2018).

Otchet ob ispolnenii plana realizacii gosudarstvennoj programmy Rostovskoj oblasti «Ohrana okruzhajushhej sredy i racional'noe prirodopol'zovanie». Oficial'nyj portal Pravitel'stva Rostovskoj oblasti, 2018, 30 maja. URL: https://www.donland.ru (accessed 30 May 2018).

Oficial'naja statistika. Territorial'nyj organ Federal'noj sluzhby gosudarstvennoj statistiki po Volgogradskoj oblasti ot 26.05.18. URL: http://volgastat.gks.ru/wps/ $\mathrm{wcm} /$ connect/rosstat_ts/ru/statistics/ (accessed 19 December 2018).

Oficial'naja statistika. Territorial'nyj organ Federal'noj sluzhby gosudarstvennoj statistiki po Rostovskoj oblasti ot 26.05.18. URL: http:/ /rostov.gks.ru/wps/wcm/connect/rosstat_ts / $\mathrm{ru} / \mathrm{statistics/employment/} \mathrm{(accessed} 10$ December 2018).

Pakina A.A, Kirillov S.N., Tul'skaja N.I. Ocenka ustojchivosti razvitija na regional'nom urovne: primer Respubliki Tatarstan [Assessment of sustainability at the regional level: an example of the Republic of Tatarstan]. Vestnik Volgogradskogo gosudarstvennogo universiteta. Serija 3, Jekonomika. Jekologija [Science Journal of Volgograd 
State University. Global Economic System], 2017, no. 4, pp. 127-137. DOI: https://doi.org/ 10.15688/jvolsu3.2017.4.14.

Ploshhad' sel'skohozjajstvennyh ugodij Rostovskoj oblasti. Sel'skoe hozjajstvo i APK ot 13.06.18. URL: http://www.donland.ru/ Default.aspx?pageid $=89760$ (accessed 21 February 2018).

Pljakin A.V., Orehova E.A., Bodrova V.N. Prostranstvennyj analiz struktury zemel'nogo fonda Volgogradskoj oblasti v geoinformacionnoj sisteme [Spatial analysis of the structure of the land Fund of the Volgograd region in the geographic information system]. Vestnik Volgogradskogo gosudarstvennogo universiteta. Serija 11, Estestvennye nauki [Science Journal of Volgograd State University. Natural Sciences], 2012, no. 2 (4), pp. 65-71. DOI: https://doi.org/ 10.15688/jvolsu1 1.2012.2.10.

Poligony TBO Volgogradskoj oblasti. Volga-media ot 15.06.18. URL: http://vlg-media.ru/society/ poligony-tbo-v-volgogradskoi-oblastiosnastjat-musoropererabatyvayuschimikompleksami-59321.html (accessed 21 November 2018).

Solov'eva S.V. Jekologicheski ustojchivoe razvitie Moskvy: indikatory i indeksy [Sustainable development of Moscow: indices and indicators]. Sociologija i estestvoznanie: mezhdisciplinarnye podhody $k$ izucheniju social'noj real'nosti: sb. nauch. st. i materialov Vserossijskoj nauchnoj konferencii. Moscow, 2014, pp. 24-27.
Ukaz Prezidenta Rossijskoj Federacii ot 01.04.1996 № 440 «O Koncepcii perehoda Rossijskoj Federacii k ustojchivomu razvitiju». Konsul tant Pljus: inform. sistema, 2018, 26 fevralja (accessed 03 November 2018).

Bobylev S.N. Ustojchivoe razvitie: metodologija $i$ metodiki izmerenija: ucheb. posobie [Sustainable development: methodology and methods of measurement: learning. benefit]. Moscow, Jekonomika, 2011. 358 p.

CUR i Rossija. Celi ustojchivogo razvitija ot 18.04.18. URL: http://www.globalcompact.ru/index/czeliustojchivogo-razvitiya.html (accessed 05 November 2018).

Jashalova N.N. Analiz projavlenija jeffekta dekaplinga v jekologo-jekonomicheskoj dejatel'nosti regiona [Sustainable development of Moscow: indices and indicators]. Regional'naja jekonomika: teorija i praktika, 2014, no. 39, pp. 54-61.

Elkington J. The Triple Bottom Line: Does it All Add Up? Assessing the Sustainability of Business and CSR. London, Earthscan Publications, 2004, pp. 1-16.

Polese M., Stren R. The Social Sustainability of Cities: Diversity and Management of Change. Toronto, University of Toronto Press, 2000, pp. 15-16.

Bobylev S., Perelet R., eds. Sustainable Development in Russia. Berlin; St. Petersburg, 2013. 206 p.

Urbaniec M. Sustainable Development Indicators in Poland: Measurement and System Evaluation. Entrepreneurial Business and Economics review, 2015, no. 1, pp. 119-133.

\section{Information about the Authors}

Elena A. Ivantsova, Doctor of Sciences (Agriculture), Professor, Head of the Department of Ecology and Nature Management, Volgograd State University, Prosp. Universitetsky, 100, 400062 Volgograd, Russian Federation, ivantsova.volgu@mail.ru, https://orcid.org/0000-0003-4265-9703

Margarita V. Postnova, Doctor of Sciences (Biology), Professor, Head of the Department of Bioengineering and Bioinformatics, Volgograd State University, Prosp. Universitetsky, 100, 400062 Volgograd, Russian Federation, postnova@volsu.ru, https://orcid.org/0000-0001-6988-6389

Vadim A. Sagalaev, Doctor of Sciences (Biology), Professor, Head of the Department of Biology, Volgograd State University, Prosp. Universitetsky, 100, 400062 Volgograd, Russian Federation, bot@volsu.ru, https://orcid.org/0000-0001-7276-7129

Anna A. Matveeva, Candidate of Sciences (Agriculture), Associate Professor, Department of Ecology and Nature Management, Volgograd State University, Prosp. Universitetsky, 100, 400062 Volgograd, Russian Federation, matveeva@volsu.ru, https://orcid.org/0000-0002-2567-9860

Anna V. Kholodenko, Candidate of Sciences (Geography), Associate Professor, Department of Ecology and Environmental Management, Volgograd State University, Prosp. Universitetsky, 100, 400062 Volgograd, Russian Federation, a.v.kholodenko@bk.ru, https://orcid.org/0000-0001-9053-9373 


\section{Информация об авторах}

Елена Анатольевна Иванцова, доктор сельскохозяйственных наук, профессор, заведующий кафедрой экологии и природопользования, Волгоградский государственный университет, просп. Университетский, 100, 400062 г. Волгоград, Российская Федерация, ivantsova.volgu@mail.ru, https://orcid.org/0000-0003-4265-9703

Маргарита Викторовна Постнова, доктор биологических наук, профессор, заведующий кафедрой биоинженерии и биоинформатики, Волгоградский государственный университет, просп. Университетский, 100, 400062 г. Волгоград, Российская Федерация, postnova@volsu.ru, https://orcid.org/0000-0001-6988-6389

Вадим Александрович Сагалаев, доктор биологических наук, профессор, заведующий кафедрой биологии, Волгоградский государственный университет, просп. Университетский, 100, 400062 г. Волгоград, Российская Федерация, bot@volsu.ru, https://orcid.org/0000-0001-7276-7129

Анна Александровна Матвеева, кандидат сельскохозяйственных наук, доцент кафедры экологии и природопользования, Волгоградский государственный университет, просп. Университетский, 100, 400062 г. Волгоград, Российская Федерация, matveeva@volsu.ru, https:/orcid.org/0000-0002-2567-9860

Анна Викторовна Холоденко, кандидат географических наук, доцент кафедры экологии и природопользования, Волгоградский государственный университет, просп. Университетский, 100, 400062 г. Волгоград, Российская Федерация, a.v.kholodenko@bk.ru, https://orcid.org/0000-0001-9053-9373 